\title{
What Problems Can Dollarization Solve? ${ }^{1}$ \\ Barry Eichengreen \\ University of California, Berkeley
}

January 2001

Those of us who are skeptical about the viability of intermediate exchange-rate arrangements find ourselves tempted to climb aboard the dollarization bandwagon. I may be the most extreme and unreformed proponent in this room of the view that high capital mobility has made it exceedingly difficult -- and in any case undesirable -- to operate pegged-but-adjustable exchange rates, target zones, crawling pegs, and other arrangements that specify explicit limits on how far the exchange rate can move but that do not entail the commitment of a currency board or dollarization. Intermediate regimes are fragile. Operating them is tantamount to painting a bull's eye on the forehead of the central bank governor and telling speculators to "shoot here." History shows that intermediate regimes collapse sooner or later. ${ }^{2}$ And when they do they heighten the severity of subsequent crisis, because the implicit ex ante insurance against exchange risk they provide encourages banks and corporates to accumulate unhedged exposures, heightening financial dislocations when the denouement comes. For an exchange rate economist, this may be the most important lesson of the Asian crisis. ${ }^{3}$

It follows that only two alternatives remain: a more freely floating currency whose

${ }^{1}$ Prepared for an ASSA panel on dollarization chaired by Dominick Salvatore, and forthcoming in The Journal of Policy Modeling. This talk draws on my article "When to Dollarize," forthcoming in The Journal of Money, Credit and Banking.

${ }^{2}$ As documented by the work of Klein and Marion (1997).

${ }^{3}$ See for example Goldstein's (1998) analysis of the problem. 
management does not involve an explicit range or target for the rate, or a hard peg in the form of a currency board or dollarization. ${ }^{4}$

Given that countries must move to these extremes, we can presumably invoke standard optimum-currency-area considerations to determine who should float and who should dollarize. These criteria suggest that El Salvador is a candidate for dollarization: it is small, open, and tightly linked to the United States both commercially and financially. Brazil should float because it is larger and more open and because its trade and finances are more diversified. Argentina is a disputed case because it is in the middle: it is neither as small as El Salvador nor as large as Brazil. This is how authors like John Williamson (2000) see the cases for and against dollarization. ${ }^{5}$

In fact, this approach is almost completely orthoginal to the issues at the heart of the dollarization debate. That debate is about financial stability and whether dollarization is a means

${ }^{4}$ The conclusion that they should exhibit what The Economist calls "zeal for the extremes" applies to countries that are integrated into international financial markets; for those prepared to retain capital controls, other (intermediate) arrangements are of course possible. To be clear, the implication is not that countries are left with the options of floating freely versus dollarizing, but that intervention should not be framed as an explicit target for the exchange rate. Such targets set the authorities up as sitting ducks for speculators, and they encourage the misapprehension on the part of banks and corporates that they will be protected against exchange rate movements, encouraging the accumulation of unhedged exposures. The greater uncertainty created by the absence of explicit ex ante limits on far the exchange rate is allowed to move is better from these points of view both because it creates more of a two-way bet for speculators and because it provides a continuous reminder to banks and corporates that they should take exchange risk into account when formulating their financial plans. Guillermo Calvo and Carmen Reinhart (2000) have provided convincing evidence that many emerging markets which have abandoned official exchange rate targeting regimes continue to intervene in the foreign exchange market to limit currency movements. But, precisely because that intervention is not framed in terms of an explicit exchange rate target, their observation is by no means inconsistent with my view.

${ }^{5}$ The irony is that Williamson is himself the leader defender of the view that intermediate exchange rate arrangements are still viable, which from this point of view makes the issue of dollarization less pressing. 
of enhancing it. It is about fiscal stability and whether budget balance is easier to attain after dollarization. It is about economic reform and whether dollarization is an effective means of encouraging it. These are issues about which the theory of optimum currency areas has little to say.

To be clear, I am not asking whether reforms of the banking sector, the financial sector, the fiscal accounts and the labor market are prerequisites for dollarization. While there is a large literature on this subject, the question it addresses is analytically distinct. ${ }^{6}$ My own reading is that this debate is over. There is by now an overwhelming body of evidence that countries can effectively solve the exchange rate problem — that is to say, they can effectively eliminate exchange rate instability — by dollarizing or installing a currency board without first having to satisfy a long list of economic preconditions like strengthening their banking systems, balancing their budgets, funding their public debts, and removing labor market rigidities. The economies that have dollarized or adopted currency boards in the last decade — from Ecuador to Estonia, from Bulgaria to El Salvador — have done so without first eliminating these problems. Indeed, countries like Ecuador and Argentina have dollarized or installed currency boards not because they succeeded in pushing through other reforms but precisely because their economic and financial problems have proven so intractable. They have done precisely in order to prevent those problems from spilling over into the currency market. And the fact that dollarization and currency boards, once adopted, have stuck confirms that this is a perfectly feasible way of insulating the currency market from these other problems. My reading of the scholarly discourse is that the economics profession is now in broad agreement with this view.

\footnotetext{
${ }^{6}$ See for example Hanke (2000).
} 
But, to repeat, this is not the question I am asking. I am not challenging the now conventional wisdom that dollarization is feasible prior to economic reform. Rather, I am asking whether dollarization is more likely to speed or slow economic and financial reform generally. This is what we should care about. Countries with screwed-up banking systems, budgets, and labor markets will perform miserably when the exchange rate is collapsing and inflation is running out of control, but they will perform just as miserably if the national currency is replaced by the dollar but these other problems remain unsolved. Their economic performance will be dismal whether they use someone else's currency or their own. Is dollarization the answer? It is if and only if it delivers solutions to these other problems.

$$
\text { ****** }
$$

What do we know about the effect of dollarization on the pace of fiscal, financial and labor-market reform. While there exist a few theoretical models linking the exchange rate regime to fiscal, financial and labor-market outcomes, and while we use evidence from countries with pegged and floating rates to argue by analogy, the honest answer is "not much."

Financial Sector Reform. There are two versions of the argument that dollarization will encourage reform of the banking system. One is that by constraining the ability of the monetary authority (and perhaps also the fiscal authorities) to lend in the last resort, dollarization will compel bank owner-managers to acknowledge that they are no longer protected by the financial safety net. The realization that the authorities regard them as too big and important to fail encourages banks to engage in imprudent behavior, and only a hard constraint on the ability of the central bank to aid ailing banks by injecting domestic credit into the financial system can compel 
them to shape up. This is how some advocates of dollarization interpret Turkey's crisis: Turkish banks were encouraged to take short-term open foreign currency positions, exposing them to excessive and ultimately unmanageable exchange risk, by the knowledge that the Turkish central bank was operating a soft peg which could be let go if it became necessary to bail out the banking system. Dollarization would have been a better alternative for the country. ${ }^{7}$

But if it is implicit ex ante insurance against exchange risk (that is, the government's promise that the exchange rate will not be allowed to change unexpectedly) that encourages the accumulation of unhedged foreign-currency exposures, then greater exchange rate flexibility can be as effective as dollarization in discouraging this form of excessive risk taking. ${ }^{8}$ Dollarization may be a solution, but so too may greater exchange-rate flexibility. Which currency regime is more conducive to reform -- dollarization or floating -- depends on which form of moral hazard — the financial safety net or the exchange-rate guarantee — is more serious.

Ultimately, this issue can only be resolved empirically. I have examined it by extending a model of banking crises estimated previously in joint work with Andy Rose. ${ }^{9}$ I find that it is intermediate exchange-rate regimes (neither hard pegs nor floats) are most strongly associated with crises; this is support for the view that these encourage the accumulation of unhedged

${ }^{7}$ See Hanke (2000a,b) on the Turkish case. More generally, George Kaufman (1996) has noted the tendency for U.S. banks to hold larger amounts of capital and liquidity prior to the inauguration of the financial safety net. Gary Gorton (1984) similarly emphasizes the greater tendency for banks to engage in peer monitoring, thereby limiting the moral hazard from mutual assistance, prior to the founding of the Fed.

${ }^{8}$ Burnside, Eichenbaum and Rebello (1999) model the determinants of open foreigncurrency positions and their dependence on the exchange-rate regime.

${ }^{9}$ See Eichengreen and Rose (1998). The results I discuss here are reported in full in Eichengreen (2000). 
foreign exposures that cause financial distress when the exchange-rate regime is placed at risk. When I distinguish currency boards and dollarized economies from other fixed rate arrangements), it turns out that the hard pegs are associated with an unusually great incidence of banking crises. I hesitate to interpret this as suggesting that currency boards and dollarization undermine financial stability, given the small number of observations we have for currency-board and dollarized economies and the possibility of reverse causality. ${ }^{10}$ But these results shift the burden of proof.

The other argument, prominently associated with Ricardo Hausmann, is that dollarization enhances financial stability not by discouraging excessive risk taking but by promoting the development of domestic financial markets. ${ }^{11}$ The prevalence of currency and maturity mismatches in emerging financial markets, and the consequent fragility of the latter, reflect distrust of the national currency. Banks and firms funding themselves abroad are unable to borrow in the domestic currency. Since this leaves them saddled with mismatched dollar liabilities and domestic-currency-denominated assets, they get smashed whenever the currency depreciates. And so long as currency depreciation remains a possibility, foreigners will be reluctant to lend, domestics to borrow, given the danger of bankruptcy and default. The domestic financial system will remain shallow and crisis prone.

Similarly, where there is a legacy of distrust in the currency, firms with long-term

${ }^{10}$ The fact that I lag the exchange-rate/currency regime in my banking-crisis equations reduces the danger of reverse causality, but there is still the possibility that what we are observing in the data is the tendency for countries with chronic financial problems to opt for a currency board or to dollarize.

${ }^{11}$ See for example Hausmann (1999). 
investment projects will be unable to fund them using long-term loans. Domestic intermediation will be skewed to the short end, saddling balance sheets with maturity mismatches. If the exchange rate is attacked, requiring the authorities to raise short-term interest rates, debtservicing costs will rise relative to revenues, creating the danger of cascading bankruptcies. Given these dangers, the level of intermediation will be less. Again, the financial system will be narrow, fragile and likely to require lending in the last resort.

Eliminating the domestic currency solves these problems in a stroke. Currency risk disappears, making it easier for firms with long-term projects to borrow long term at home as well as abroad. (It is assumed, in other words, that it was currency risk that previously impeded the emergence of a long-term market.) Currency mismatches having been eliminated and maturity mismatches having been attenuated, the main threats to banking stability will be removed.

The dramatic impact of European monetary unification on the growth and development of European financial markets is supportive of this view. By eliminating Europe's second-tier currencies and generating economies of scale and scope, EMU has led to a dramatic rise in the liquidity of European financial markets. It has allowed European corporations to fund long-term investment projects by floating long-term loans to a much greater extent than was possible so long as each of the members of the monetary union issued its own national currency. ${ }^{12}$ Recent work by Hausmann, Gavin, Pages-Serra and Stein (2000) suggests more generally that countries with pegged exchange rates are able to issue more of their external debt long term and denominate more of their debt in the domestic currency.

\footnotetext{
${ }^{12} \mathrm{~A}$ thorough analysis of these effects can be found in Danthine, Giavazzi and von Thaden (2000).
} 
There are reasons to pause before accepting these findings. These are inconsistent with the large literature on financial deepening in which it is not the exchange-rate regime per se that is associated with financial deepening but whether inflation and currency depreciation are rapid, uncertain and disruptive. ${ }^{13}$ For countries like Canada and Australia, floating and deep domestic financial markets are entirely compatible. Only if one believes that stable floating is an oxymoron is the case for dollarization strong.

Fiscal Reform. Similarly, there are two arguments that dollarization will produce quick consolidation of the public finances. First, by eliminating inflation, dollarization will bring interest rates down to world levels, reducing debt servicing costs. Second, by removing the inflation tax as a revenue source of last resort, it will force governments to live within their means.

It is of course the second mechanism that is key. The way to understand it is in terms of Sargent and Wallace's game of "chicken" (Sargent 1986). ${ }^{14}$ The central bank asserts that it will not engage in inflationary monetization under any circumstances in the hope of forcing the fiscal authorities to reduce the budget deficit. The fiscal authorities counter that they will not reduce the budget deficit under any circumstances, hoping to induce the central bank to monetize the excess to prevent a steep rise in interest rates, a debt default, or some other unacceptable consequence. If the monetary authority retains the option of backing down and monetizing, then the fiscal authority may prevail. But if the commitment not to monetize is fully credible, as it will be if the economy is dollarized, then the fiscal authority, if it regards the costs of default as

\footnotetext{
${ }^{13}$ I return to this point below.

${ }^{14}$ This is of course a familiar scenario from the literature on European monetary unification; see Buiter and Kletzer (1990), on which I draw.
} 
prohibitive, will back down. Fiscal consolidation will result.

But, in most countries, fiscal policy is not made by a single centralized authority.

Municipal, state and central fiscal authorities have to agree on how to share the cuts. Introduce a little bit of uncertainty into the model (for example, uncertainty about the discount rates of the different fiscal authorities, as in Alesina and Drazen's model of the war of attrition), and eliminating the inflation tax could precipitate debt default rather than fiscal consolidation, leaving the country worse rather than better off (under the assumption that default is more costly than inflation).${ }^{15}$ This suggests that dollarization makes the most sense in countries where the fisc is centralized or there exist mechanisms for assuring coordination among the various fiscal authorities. ${ }^{16}$

${ }^{15}$ See Alesina and Drazen (1991).

${ }^{16}$ Elsewhere, I have adapted Tornell and Velasco's $(1995,1998)$ model of exchange rate policy and fiscal consolidation to analyze this problem. This model lays bare the assumptions behind the premise that dollarization encourages fiscal consolidation. This result rests on the assumption that dollarization is more credible and permanent than a simple exchange-rate peg. Because the fiscal authority in a dollarized economy knows that there is no prospect of additional inflationary finance not just now but also in the future (this is where the greater permanence of this monetary regime comes in), it has a stronger incentive to cut spending now and to more efficiently distribute it across periods. Eliminating the inflation tax will require other taxes to be increased, ceteris paribus. If distortions are increasing in the level of taxation, then this will strengthen the incentive to cut spending now as a way of balancing the budget. However, this result also rests on the assumption of no Ponzi finance -- that the government is not permitted to default on its debt. If it is assumed that politicians have to live within their means -- that the intertemporal budget constraint holds -- than of course the model will deliver the result that eliminating the inflation tax once and for all produces an intertemporally balanced budget. Similarly, if politicians still derive private benefits from additional government outlays and have a higher discount rate than other agents (for example, because they may no longer be in office in future) periods, they will still be tempted to undertake excess spending now and let someone else deal with the consequences later. How their successors will then deal with those consequences is unclear. To be sure, if the costs of default are even higher than the costs of inflation, then dollarization will increase the pressure for higher taxes and spending cuts to deal with the consequences down the road. But if the parties involved are not willing collectively to bear the 
European experience is consistent with this view. The fear that fiscal profligacy could precipitate debt-servicing difficulties with serious cross-border repercussions in a fiscallydecentralized Europe explains why the Maastricht Treaty features a set of procedures designed to avert excessive debts and deficits along with penalties for countries failing to comply. Even a European Central Bank firmly committed to price stability may be tempted to renege on that commitment if faced with a fiscally-induced financial crisis. The Maastricht Treaty and the Stability Pact negotiated subsequently are designed to limit this danger. ${ }^{17}$

Labor Market Reform. The intuition for the belief that dollarization will hasten labor market reform is as follows. Unions negotiate a path for nominal wages extending into the future. The authorities can then use monetary policy to partially offset any resulting unemployment. Unions will be aware of the ability of the monetary authorities to respond in this way and have an incentive to anticipate that response when negotiating wages; this will partly limit the capacity of an inflation-averse monetary authority to respond to unemployment with expansionary monetary policy. But only partly: under discretionary monetary policy there will be a lower variance of unemployment as well as a higher average rate of inflation. ${ }^{18}$ Hardening the exchange rate

burden, the result could be a messy and costly default rather than the hoped-for fiscal consolidation.

${ }^{17}$ A Latin American dollarizer that experienced a debt crisis would likely be left by the Fed to stew in its own juices; a dollar bloc would lack the political solidarity that could impel the ECB to run to rescue a European country in this plight. A crisis that led to an inflationary debt bailout in Europe would instead precipitate a default in Latin America. Hence, the United States would not demand Maastricht-like provisions of a Mexico or Argentina that chose to dollarize unilaterally. The reason, however, would not be because dollarization removes the danger of default. It does not.

${ }^{18}$ This is the prediction of the Barro-Gordon model. 
constraint thus will increase the variability of unemployment, other things equal. If unions regard more variable unemployment unfavorably, dollarization will provide additional incentive for reform.

Or will it? Drawing on work by Lars Calmfors, I have analyzed the consequences of extending the Barro-Gordon model to include in the government's loss function not just inflation and unemployment but also the amount of (costly) labor market reform, where equilibrium unemployment is declining in the level of reform. ${ }^{19}$ In the standard one-shot game, there is an optimal amount of labor-market reform whose costs are just matched by the benefits in terms of the reduction in equilibrium unemployment (and hence expected unemployment) plus the benefits of the reduction in inflation (because lower equilibrium unemployment reduces inflationary bias). With dollarization, labor market reform no longer results in a lower average rate of inflation. Hence, labor market reform following dollarization is less, not more. Other results can be obtained by modifying the specification slightly. But this result should disturb the advocates of dollarization.

What about the evidence? Observers of Argentine convertibility will be skeptical that a hard exchange rate constraint accelerates the process of labor market reform. But perhaps Argentina has not seen more labor market reform because convertibility remains less than credible. This is why it is argued that it is necessary to take the additional step of dollarizing. This makes it useful to also consider Europe, where the commitment to exchange-rate stability is long standing and monetary union is essentially irreversible. As in Argentina, there is some evidence of reform, and unemployment is beginning to come down. The question, though, is

\footnotetext{
${ }^{19}$ See Calmfors (1998).
} 
whether this is a cyclical or a structural phenomenon. It is suggestive that some of the countries undertaking the most extensive reforms -- the Netherlands for example — have also had a hard exchange-rate commitment for longest. But there are also counterexamples -- countries like the UK, which have neither participated in the ERM for any period of time nor committed to the monetary union, where labor markets have been rendered significantly more flexible since the late 1970s. If one constructs an index of the extent of labor market reform from the reforms tabulated by the OECD (1999), then a simple t-test for differences suggests no difference of the extent of reform between countries with and without hard exchange-rate constraint.

What are the implications for dollarization? Theory cannot tell us whether dollarization will speed or slow labor market reform. There are conditions under which reform of the labor market will accelerate, and many people's intuition will tell them that these are the plausible conditions. There is some anecdotal evidence that a hardening exchange-rate commitment and monetary union are encouraging efficiency-enhancing reforms in Argentina and Europe, but systematic analysis suggests that reform remains partial and incomplete.

$$
* * * * *
$$

What lessons can we draw from this discussion? Let me leave you with four.

- The first one is humbling for an exchange rate economist. In our preoccupation with the exchange rate, we pay too much attention to the choice between pegging and floating and between retaining the national currency versus adopting that of someone else. It is not the color of the currency in one's wallet but the level of living standards and the rate of 
economic growth that we should care about. The literature on the link between the exchange rate regime and economic growth is inconclusive; one can find in it an almost uniform distribution of significant and insignificant results. But even those studies which conclude in favor of a positive link acknowledge that the effect is small. ${ }^{20}$ Other variables, be they the development of markets and institutions or the accumulation of human capital, are more important determinants of economic growth. We are interested in the exchange rate regime and alternatives like dollarization only insofar as there is a plausible case that they can play a role in putting in place these fundamental prerequisites for growth. But the fact that countries have succeeded in sustaining growth under a variety of exchange rate regimes and currency arrangements suggests that, for those interested in the mainsprings of growth, this is not the first place to look for such prerequisites.

- Second, since the exchange rate is a financial variable, the most plausible link is between dollarization and the development of financial markets. Thus, I find quite provocative recent work suggesting that countries that peg their exchange rates have deeper and more

\footnotetext{
${ }^{20} \mathrm{~A}$ notable exception is Frankel and Rose (2000). Because these authors find a very large effect of a common currency on the volume of trade, even a moderate positive impact of trade on growth means that dollarizing will have an economically significant impact on living standards in the medium term. But I for one remain unconvinced that their dummy variable for countries sharing a currency is really picking up the effect of currency unification on trade, as distinct from the effects of other economic, social, military and political links that encourage countries to adopt the same currency but also lead them to engage in additional trade. The point applies equally to the European Union (where currency unification is part of a larger economic and political bargain stretching back over a period of decades) and trade between the major powers and the microstates that use their currencies, the two of which account for the bulk of common currency cases in the Frankel-Rose data set.
} 
liquid financial markets. ${ }^{21}$ But I am not sure whether the association between financial development and currency stability reflects the causal impact of the latter on the former or simply the ability of some governments to make credible commitments - in other words, it may reflect an omitted factor that creates a spurious correlation between the two variables of interest. I regard this as an important issue for research.

- Third, the key issue for crisis countries is whether dollarization will accelerate or retard economic reform. If dollarization accelerates fiscal, financial and labor market reform, then it is a way out of the crisis. If it slows reform, then it is part of the problem, not part of the solution. And if it has no first-order effect on the pace of reform, then it is largely irrelevant.

- $\quad$ Fourth and finally, these are issues on which theory provides little guidance. Results from analytical models of whether reform is more or less likely under a particular currency and exchange rate regime are sensitive to small changes in specification. As usual, it is possible for clever theorists to build models that point in both directions. What is needed is systematic empirical work on the links from the exchange rate regime to the pace, scope and credibility of economic reform. Until we have it, we will be unable to say with confidence whether dollarization is a good or bad idea.

${ }^{21}$ See Hausmann, Gavin, pates-Serra and Stein (2000) and Levine and Carkovic (1999). Note that Hausmann et al. and Levine and Carkovic advance rather different interpretations of the link from the exchange rate to growth. Hausmann et al. Argue that it is the stability of the exchange rate per se that is conducive to financial deepening and development. Levine and Carkovic find no evidence that the volatility of the exchange rate is related to development, financial or otherwise. But they do confirm the findings of other work to the effect that the rate of inflation is positively associated with financial development. And the rate of inflation is presumably something that an inflation-prone country can affect by adopting the currency of a neighbor more deeply committed to price stability. 


\section{References}

Alesina, Alberto and Allan Drazen (1991), "Why Are Stabilizations Delayed?" American Economic Review 81, pp.1170-1188.

Burnside, Craig, Martin Eichenbaum and Sergio Rebello (1999), "Hedging and Financial Fragility in Fixed Exchange Rate Regimes,” NBER Working Paper no.7143 (May).

Buiter, Willem and Kenneth Kletzer (1990), "Reflections on the Fiscal Implications of a Common Currency," CEPR Discussion Paper no. 418 (May).

Calmfors, Lars (1998), "Unemployment, Labour-Market Reform, and Monetary Policy," unpublished manuscript, Institute for International Economic Studies, Stockholm University (1998).

Organisation for Economic Cooperation and Development (1999), Implementing the OECD Jobs Strategy: Assessing Performance and Policy, Paris: OECD.

Calvo, Guillermo and Carmen Reinhart (2000), "Fear of Floating," NBER Working Paper no. 7993 (November).

Danthine, Jean-Pierre, Francisco Giavazzi and Ernst-Ludwig von Thaden (2000), "European Financial Markets After EMU: A First Assessment," NBER Working Paper no. 8044 (December).

Eichengreen, Barry (2000), "When to Dollarize," Journal of Money, Credit and Banking (forthcoming).

Eichengreen, Barry and Andrew Rose (1998), "Staying Afloat When the Wind Shifts: External Factors and Emerging-Market Banking Crises," NBER Working Paper no. 6370 (January).

Frankel, Jeffrey A. and Andrew K. Rose (2000), "Estimating the Effect of Currency Unions on Trade and Output," NBER Working Paper no. 7857 (August).

Goldstein, Morris (1998), The Asian Financial Crisis, Washington, D.C.: Institute for International Economics. 
Gorton, Gary B. (1984), "Private Clearinghouses and the Origins of Central Banking," Business Review of the Federal Reserve Bank of Atlanta (January/February), pp.3-12.

Hanke, Steve H. (2000a), “The Disregard for Currency Board Realities," Cato Journal 20, pp.4959.

Hanke, Steve H. (2000b), "How to Forestall International Rescue: Currency Boards in Turkey and Argentina Could have aved the IMF from Having to Bail Them Out Again," Financial Times (12 December), p.15.

Hanke, Steve H. (2000c), “Letter to the Editor,” Financial Times (19 December), p.14.

Hausmann, Ricardo, "Should There Be Five Currencies or One Hundred and Five?" Foreign Policy 116 (1999), pp.65-79.

Hausmann, Ricardo, Michael Gavin, Carmen Pages-Serra and Ernesto Stein (2000), "Financial Turmoil and the Choice of Exchange Rate Regime," unpublished manuscript, Interamerican Development Bank.

Kaufman, George G., "Bank Fragility: Perception and Historical Evidence," Issues in Financial Regulation Working Paper 96-18, Federal Reserve Bank of Chicago (September 1996).

Klein, Michael and Nancy Marion (1997), "Explaining the Duration of Exchange Rate Pegs," Journal of Development Economics 54, pp.387-404.

Levine, Ross (1999) and Maria Carkovic (1999), "How Much Bang for the Buck? Mexico and Dollarization," unpublished manuscript, University of Minnesota.

Sargent, Thomas (1986), Rational Expectations and Inflation, New York: Harper and Row.

Tornell, Aaron and Andres Velasco (1995), "Fiscal Discipline and the Choice of Exchange Rate Regime," European Economic Review 39, pp.759-770.

Tornell, Aaron and Andres Velasco (1998), "Fiscal Discipline and the Choice of a Nominal Anchor in Stabilization," Journal of International Economics 46, pp.1-30.

Williamson, John (2000), "Dollarization Does Not Make Sense Everywhere," revised outline of remarks delivered to the North-South Institute, Ottawa, Canada, http://www.iie.com/testimony/ jwdollar.htm. 